\title{
Development of the Referral Vocational High Schools based on the Students Quantity and Networking Road Maps in Malang Raya
}

\author{
$1^{\text {st }}$ Ewit Irniyah \\ Graduate Education \\ State University of Malang \\ Malang, Indonesia \\ ewit_irniyah@ymail.com
}

\author{
$2^{\text {nd }}$ Amat Mukhadis \\ Department of Mechanical Engineering \\ State University of Malang \\ Malang, Indonesia \\ mukhadis_s@yahoo.com
}

\author{
$3^{\text {rd }}$ Tri Atmadji.S \\ Department of Electronic Engineering \\ State University of Malang \\ Malang, Indonesia \\ atmadji_tri@yahoo.com
}

\begin{abstract}
This study aims to reveal and describe the development of referral SMK based on the road map of the student's quantity and networking in Malang Raya. The population in this study was 11 schools then using Proportional random sampling technique with Slovin formula obtained 5 schools, each school representing Malang city, Malang district, and Batu city. Data were collected using documentation, questionnaires, and interviews. Data analysis used descriptive statistics with percentages and averages. The research shows that the student's quantity in SMK Malang raya from 2014 to 2015 for the Malang city has an average of more than 1000 students, in Malang district there is one school that has less than 1000 students, and in the Batu city does not exist schools that have more than 1000 students. The number of industrial cooperation with SMK in Malang Raya has increased from 2014 to 2016. SMK in malang city has cooperation up to 228 industrial partners, SMK in malang district has cooperation up to 177 industrial partners, and SMK in Batu city only has cooperation up to 120 industrial partners. The conclusion of the research is the students quantity road map for the Malang city has fulfilled the signs of the referral vocational school, one of the vocational schools in Malang district has not met the minimum standard number of the referral vocational school, then the referral vocational school in Batu city area has not fulfilled the minimum standard number of students. The development of networking road map has met the standard of reference SMK with a minimum number of cooperation $100 \mathrm{SMK}$; students quantity road map; networking road map
\end{abstract}

\section{INTRODUCTION}

Improving the quality of education has never ceased to improve the education system, the ministry of education and culture through the Directorate of Vocational High School Development (Directorate of PSMK, 2015) pioneered the development of vocational high school model called the referral SMK. The Referral Vocational School has superior performance, great and effective access to institutional management as a model, reference and enforcement of target schools that can be used as a reference for the surrounding vocational schools (Directorate of PSMK, 2015). This Referral Vocational School will be the main school (alliance) for 3 or 4 SMKs of a smaller scale whose location is not far apart in an area. The vocational alliance can utilize the facilities and resources contained in its reference vocational school. The reference vocational school can facilitate training and education to learners, implement KKNI-based graduate qualification standards, improve teacher quality, as well as improve other services including providing services to vocational schools (alliances).

The partnership between business and school is a partnership to gain input or profit for both parties. Partnerships in cooperation can increase human resources and reduce unemployment. The partnership relationship between the business world and SMK is a form of welfare for both parties to improve the quality for the business world and increase the graduates who are absorbed in the business world (Kurniasari \& Isnani, 2015). Research from Ixtiarto \& Sutrisno (2016) shows the results of partnership planning in SMK Muhammadiyah 2 Wuryantoro have potential in cooperating with the industrial world such as; a) planning school promotion in establishing communication with the business and industry world and curriculum synchronization; b) taking advantage of the specific roles of business and industry as guest teachers, and scholarships; c) business and industry cooperation established in the MOU whose contents of cooperation are agreed to include in the curriculum synchronization.

Development of referral SMK poses a problem if the development of vocational school is not accompanied by the number of students who have been determined directorate PSMK. Cooperation between schools and the industrial world is needed to create competent graduates in accordance with the objectives of the referral SMK. With the cooperation made by the school with the industrial world, is expected to create opportunities for schools to prepare students in the face of competition in the world of work in the future.

\section{METHOD}

The research design is an alternative strategy to solve the problems studied. The research design in problem solving consists of activities of various kinds (Mukhadis, 2016:220). In accordance with the problem, this research is designed as a quantitative descriptive study. The population in this study is the referral SMK in Malang Raya both public and private schools. The population consists of 11 the referral SMK in 
Malang Raya with the number of samples is 5 SMK which is representative of each city and district by using proportional random sampling technique. Data collection by documentation and interview. Data analysis using "mean" technique to know the average student's quantity and networking of the referral SMK in Malang Raya.

\section{RESULTS}

\section{A. The Students Quantity Road Maps}

This study describes the road map of the student's quantity in the referral SMK that located in Malang City, Malang District, and Batu City. The student's quantity refers to BIMTEK of referral SMK, apart from BIMTEK of referral SMK there are influencing factor that is: 1) gender of male and female students; and 2) the number of each study group in the referral vocational school.

This study describes the road map of the student's quantity from the referral SMK in Malang Raya between 2014 and 2016. The sample of this study amounted to five referral SMK. The student's quantity in the referral SMK is influenced by many factors but in this study refers to the signs in the BIMTEK referral SMK that describe the student's quantity at least 1000, for the complete data presented in Figure 1.

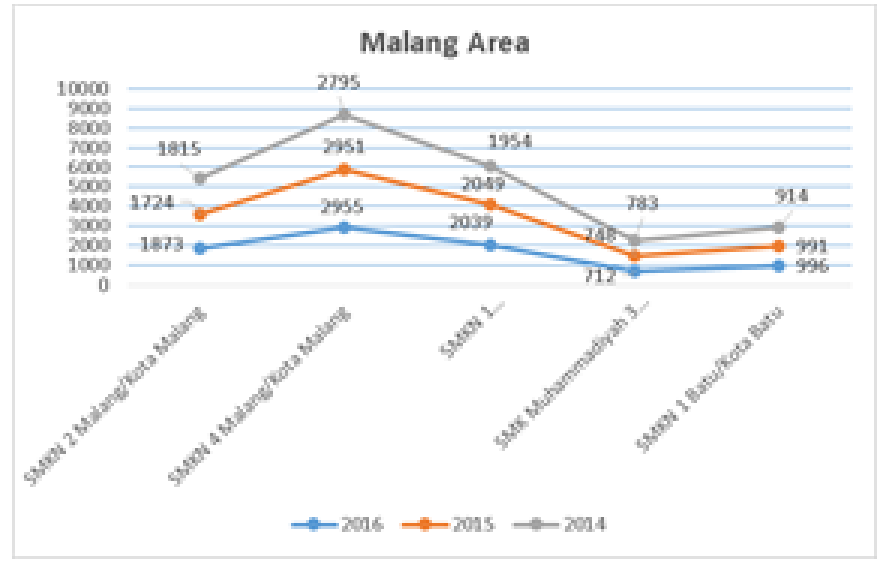

Fig. 1. The student's quantity road maps in malang raya

Referrals SMK in Malang city at Figure 1 shows that the student's quantity has been in accordance with the signs of SMK Rujukan. The year 2014 with the number of 1815 students in SMKN 2 Malang meet the criteria for the referral SMK. The year 2015 with the number of 1724 students SMKN 2 Malang meet the criteria of the number of students of referral SMK but in 2015 there was a decrease in the number of students. The year 2016 with the number of 1873 students SMKN 2 Malang meets the criteria of referral SMK, and in 2016 there is an increasing number of students after in 2015 decreased.

Criteria for referral SMK with the number of students at least 1000 students referring to the Directorate of PSMK (2015). At SMKN 4 Malang in 2014 with the number 2795 students SMKN 4 Malang meets the criteria of the referral vocational school. The year 2015 with the number of 2951 students SMKN 4 Malang meet the criteria of the referral vocational school. The year 2016 with the number of 2955 students SMKN 4 Malang meet the criteria of referral SMK. SMKN 4 Malang for the number of students has increased each year.

Referral SMK in Malang district at Figure 1 shows that the number of students refers to the signs of referral SMK. The year 2014 with the number of 1954 students in SMKN 1 Singosari meet the criteria of the referral vocational school. The year 2015 with the number of 2039 students SMKN 1 Singosari meet the criteria of the number of students referral SMK. The year 2016 with the number of 2049 students SMKN 1 Singosari meet the criteria for the referral SMK.

The reference vocational school in Batu city at Figure 1 shows that the number of students refers to the signs of the Referral SMK. The year 2014 with the number of 914 students in SMKN 1 Batu has not met the criteria of the referral vocational school. The year 2015 with the number of 991 students of SMKN 1 Batu has not met the criteria of the number of students of referral SMK. The year 2016 with the number of 996 students of SMKN 1 Batu has not met the criteria of the referral vocational school.

\section{B. The Networking Road Maps}

This study describes the industrial cooperation road map of referral SMK in Malang City, Malang District, and Batu City. The sample of this study amounted to five referral SMK. Industrial cooperation refers to BIMTEK of referral SMK. Other than BIMTEK of referral SMK, there are influencing factors are: 1) curriculum; 2) learning, and 3) practice / apprenticeship in the referral SMK.

This study describes the road map of SMK referral industry cooperation in Malang region between 2014 and 2016. The research sample amounted to five referral SMK. Industrial cooperation is influenced by many factors but in this research from the signs in BIMTEK of referral SMK industry cooperation of at least 100 industries in each referral SMK, for complete data presented in Figure 2.

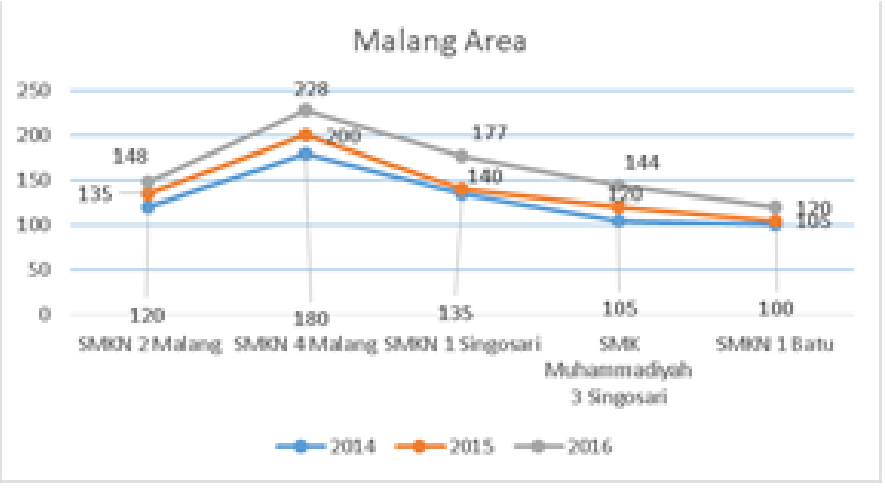

Fig. 2. The Networking road maps in malang raya

Referral SMK in the Malang city at Figure 2 shows that industrial cooperation refers to the signs of referral SMK for cooperation with the industrial world of at least 100 industries. The year 2014 with the number of 180 industries, SMKN 2 Malang meet the criteria for the referral Vocational School. 
The year 2015 with the number of 200 industries, SMKN 2 Malang meet the criteria of the number of students of referral SMK. The year 2016 with the number of 228 industries, SMKN 2 Malang meet the criteria of referral SMKN.

The referral vocational school in Malang district at figure 2 shows that cooperation with the industrial world is more than 100 industries. The year 2014 with the number of 135 industries, SMKN 1 Singosari meet the criteria for the referral SMK. The year 2015 with 140 industries, SMKN 1 Singosari meet the criteria of the number of students of the referral SMK. The year 2016 with the number of 177 industries, SMKN 1 Singos ari meet the criteria for the referral SMK.

Criteria for referral SMK having the industrial cooperation of at least 100 industries refer to Directorate of PSMK. SMK Muhammadiyah 3 Singosari in 2014 meets the criteria of SMK referral with the number of 105 industries. The year 2015 with the number of 120 industries, SMK Muhammadiyah 3 Singosari meet the criteria of referral SMK. The year 2016 with the number of 144 industries, SMK Muhammadiyah 3 Singosari meet the criteria of referral SMK.

Research data at SMK Muhammadiyah 3 Singosari through an interview with vice principal of public relations school and get information that school collaboration with industry has other factors besides from BOMTEK reference signs of the referral SMK. These factors are: 1) curriculum; 2) learning; and 3) practice / apprenticeship. The curriculum at SMK Muhammadiyah 3 Singosari from 2014 to 2015 uses the 2013 curriculum, then in 2016 uses a synchronization curriculum that coordinates from school to industry. Learning from 2014 to 2015 implements classroom practice and by 2016 implements industry-grade schools with industry. Practice / internship every year is done to establish cooperation with school and industry.

The referral SMK in the Batu city at Figure 2 shows that industrial cooperation refers to the signs of the referral SMK. in the Year 2014 with the number of 100 industries, SMKN 1 Batu meet the criteria for the referral SMK. The year 2015 with the number of 105industry, SMKN 1 Batu meet the criteria for the referral SMK. The year 2016 with the number of 120 industries, SMKN 1 Batu meet the criteria of referral SMK.

\section{DISCUSSION}

\section{A. The Students Quantity Road Maps}

Figure 1 provides information that the referral SMK in Malang city for SMKN 2 Malang 2014 amounted to 1815 students, 2015 amounted to 1724 students, and in 2016 amounted to 1873 students. The year 2014 to 2015 SMKN 2 Malang has decreased the number of students and in 2016 has increased the number of students. SMKN 4 Malang in the year 2014 amounted to 2795 students, 2015 amounted to 2951 students, and in 2016 amounted to 2955 students so that SMK in the city of Malang meet the standard of reference SMK with the number of students at least 1000 students.

Figure 1 shows the results in Malang district where the number of students in SMKN 1 Singosari in 2014 amounted to 1954 students, 2015 amounted to 2049 students, and in 2016 amounted to 2039 students with the results obtained SMKN 1 Singosari meet the standard of reference SMKN. While SMK Muhammadiyah 3 Singosari in 2014 amounted to 783 students, in 2015 amounted to 748 students, and in 2016 amounted to 712 students so that the number of students in SMK Muhammadiyah 3 Singosari for the number of students has not met the standard of reference SMK with the number of students at least 1000 students. The referrals SMK in the batu city shows the results of SMKN 1 Batu with the number of students in 2014 for 914 students, 2015 amounted to 991 students, and in 2016 amounted to 996 students so that SMK Batu city, especially in SMKN 1 Batu which has become a reference SMKN for the number of students yet fulfilling standard of referral SMK with number of student at least 1000 student.

The number of students in SMK Muhammadiyah 3 Singosari and SMKN 1 Batu that have not fulfilled the number of students of vocational reference is influenced by many things as presented by student waka one influential in the referral vocational other than gender factor, and the number of each study group also influenced by student background how to give awareness to parents of students to give freedom to children to choose school in accordance with the ability possessed. The student's background is the cause of the number of students in the referral SMK. Student background affects the number of students in the referral SMK supported by Marini \& Hamidah (2014) research with student family environment results affecting the number of students showing high yield with mean 43,93 .

Increasing the number of students the referrals SMK done by maximizing job opportunities provided by the referral SMK to understand to the parents of students how the competition in the world of work today. Understanding employment opportunities provide a positive psychological impact on students so as to assess its own potential. Students who have good job opportunity knowledge will influence their understanding in determining the choice of further education to choose. This research is supported by research of Windarto (2013) with result of student's interest equal to $-0,227$, educational information with student interest equal to $-0,181$, fulfillment of family need with student interest equal to $-0,156$, and value $F$ equal to 65,037 with sig 0,000 value with regression equation $\mathrm{Y}=44,623+0,533 \mathrm{X} 1-0,113 \mathrm{X} 2$ $0,122 \mathrm{X} 3-0,089 \mathrm{X} 4$, contribution of independent variable have influence $42 \%$ to student interest of SMP Negeri in continuing school at SMK, conclusion influence of student understanding influence student election into SMK.

This research is supported by Nurmala (2012) research with self understanding result give positive and significant influence to the interest of class IX SMK to continue to SMK with estimation $=0,36$ value $t=7,151$ and $P=0,0000$. This is also supported by Munadi research (2014) with the result of selfunderstanding of the interest of junior high school students entering vocational school in Pontianak included in the good category, a minimum value obtained by $18, \max 55$, mean equal to 39,60 median equal to 40,00 , amounting to 40 standard deviations of 6,575 .

In line with research from Munadi (2014), the quality of the vocational school to the students' interest in SMK has the 
tendency of the Good category. The minimum value obtained is 9 , the maximum value of 45 , the mean of 33.84 , the median of 34.00 , the mode of 36 and the standard deviation of 6.152 . Self-understanding has a positive and significant effect on Students' interest to continue their studies to SMK in Pontianak city is shown by $r=0,753 ; p=0,000$. Student Environment has a positive and significant effect on Students' interest to continue their studies to SMK in Pontianak City is shown by $r$ $=0,527 ; \mathrm{p}=0,000$. (4) SMK image has a positive and significant effect on Students' interest to continue their study to SMK in Pontianak City shown by $r=0,678 ; p=0,000$.

The results of this study are in line with Iskandar's research, et al. (2016), which states that external factors include family factors, school factors and community factors in choosing vocational schools with family factors $77,2 \%$, school factor $82,3 \%$, and community $58,9 \%$. This study is also supported by Ashriati research, et al. (2006) with the result of factors influencing students to choose SMK influenced by factors outside the family that is how to educate parents, relationships between family members, home atmosphere, family economic situation, understanding of parents, and cultural background.

Factors that influence the selection of study to vocational school can increase the number of students of SMK and indirectly meet the criteria for the referral SMK. This is supported by Majid's research (2012) with the result: 1) interest of SMP in Hulu Sungai Utara Regency is in the category of enough, (2) Junior self-understanding in Hulu Sungai Utara Regency is in enough category, (3) service The guidance of counseling in junior high school in Hulu Sungai Utara regency belongs to enough category, (4) SMK image at SMP in Hulu Sungai Utara Regency is in the category of enough, and (5) factors influencing interest of SMP in Hulu Sungai Regency North to enter SMK that is student self understanding with correlation coefficient $\mathrm{r}=0,527$ and test that yield value $\mathrm{p}=$ 0,000 , counseling service has correlation coefficient 0,512 and $\mathrm{n}$ t test that yield $\mathrm{p}$ value $=0,000$, and image SMK have correlation coefficient 0,504 and test $t$ which yields a value of $p$ $=0,000$.

\section{B. The Networking Road Maps}

The referrals SMK in Malang city at figure 2 shows that at SMKN 4 Malang in 2014 there is cooperation with 120 industries, in 2015 with 135 industries, and year 2016 with 140 industries, from the result obtained then SMKN 2 Malang fulfill the criterion of referral SMKN. SMKN 4 Malang in 2014 has a cooperation with 180 industries, in 2015 with 200 industries, and in 2016 with 228 industries so that for the Malang city meet the standard of reference SMK referring to the BIMTEK of referrals SMK.

The referrals SMK in Malang district at figure 2 shows the results at SMKN 1 Singosari in 2014 there is cooperation with 135 industries, 2015 with 140 industries, and in 2016 with 177 industries. While in SMK Muhammadiyah 3 Singosari in 2014 cooperates with 105 industries, in 2015 with 120 industries and in 2016 with 144 industries then the results obtained for the Malang district meet the standards of the reference SMK. Batu city area located in SMKN 1 Batu in 2014 cooperate with 100 industries, in 2015 with 105 industries and in 2016 cooperate with 120 industries then the results obtained from the Batu city meet the standard reference SMK. The conclusion of the results obtained from industrial cooperation with indicators referring to the BIMTEK or referrals SMK for Malang Raya meets the standard of referral SMK

This research is supported by research by Indriaturrahmi \& Sudiyatno (2016) with the result of: 1) the role of DUDI in pushing local government policy related to development of SMK based on local wis dom is not enough; 2) implementation of LG policy (monitoring and evaluation, providing new building units, opening new skills, funding, holding Gebyar SMK in Mataram City); and 3) the role of DUDI in the development of vocational school (the implementation of student prakerin goes well, the industry as the place of apprenticeship of the teacher, the industry is involved in the final level of student competency test, no cooperation related to the provision of facilities and infrastructure, and curriculum development in the form of curriculum workshop).

The result of research shows that curriculum development conducted by the referrals SMK with industrial world is synchronized so that the existing skill in the industry can be adjusted in school if the school has not implemented synchronization curriculum so that the competence in the curriculum will not be fully implemented, this is supported by Jatmoko research (2013) with the result of (1) the relevance of SMK curriculum of Vehicle Engineering Skills Competence with the needs of car service industry in Sleman Regency for engine sector $100 \%, 100 \%$ chassis and $91.67 \%$ electricity; (2) the competencies required by the car service industry that are not provided in the engine curriculum of $15 \%$, chas sis $4 \%$, and electricity $0 \%$; (3) competencies not required by car service industry but implemented in curriculum for engine and chassis $0 \%$, and electricity $0.08 \%$; (4) competencies required by the car service industry and are in the curriculum but not implemented in the SMK for the engine field of $22.88 \%$, chassis $14.60 \%$, and electricity $12.02 \%$. The general conclusion is that the curriculum in the relevant category, but there are some competencies that did not happen.

The forms of referral SMK cooperation with industry in Malang Raya are varies between schools, there are already have industrial class and there are not yet apply industrial class. With the industry class give a good contribution to the referral SMK in developing the potential possessed by the students because with the existence of industrial class can develop skills owned by students in this case supported by research Wibowo (2016) with the result of minimizing the gap between SMK with industry related to the field of cooperation, SMK prepares the competent workforce with the teaching factory teaching program, prakerin management, industrial visit management, and the organization of the industrial class. Solutions that can be done to improve the quality of human resources is through education by inculcating entrepreneurial spirit at every level and level of education. Strategies that can be done to improve the quality of human resources is to implement teaching factory. This is supported by Fajaryati's research (2012) with learning outcomes using teaching factory stated very good $(17,8 \%)$ by 14 teachers, good $(39,51 \%)$ by 32 teachers, not 
$\operatorname{good}(25,93 \%)$ by 21 teachers and very bad $(17.28 \%)$ by 14 teachers.

The results of this analysis are supported by Chryssolouris research, et al. (2016) with the results of using industry-class concepts to encourage entrepreneurship in schools and innovation within industries through collaboration between schools and industries. The results of this study also supported by research Retnawati, et al (2017) with the results of media learning software developed industry with the school has good quality and the remaining $44 \%$ of respondents stated that the software developed has a medium quality.

A form of cooperation conducted SMKN 2 Malang in the form of evaluation of learning. In 2014, 2015 and 2016 SMKN 2 Malang apply learning evaluation that refers to the curriculum 2013. While the form of competency test cooperation in SMKN 2 Malang 2014 to 2015 competency test conducted by the Professional Certification Institute (LSP), and for the year 2016 implemented by Professional Certification Institution (LSP) and industrial parties with industry that cooperate to give an as sessment of competence test at school. The form of cooperation undertaken by SMKN 4 Malang in the field of learning evaluation in 2014, 2015, and 2016 applies evaluation that refers to the curriculum of 2013 while competence test of 2014 implemented by Professional Certification Institution (LSP) then 2015 until 2016 implemented by Profession Certification Institution (LSP) and industries that work in each department.

A form of cooperation made SMKN 1 Singosari in the form of evaluation of learning. In 2014, 2015 and 2016, the learning evaluation refers to the curriculum of 2013 while the cooperation in the competency test at SMKN 1 Singosari, at 2014 assessment competency test conducted by Professional Certification Institute (LSP) and 2015 to 2016 competency test for assessment conducted by Certification Agency Profession (LSP) and industry. A form of cooperation in SMK Muhammadiyah 3 Singosari in the evaluation of learning, 2014 refers to the KTSP while 2015 to 2016 refers to the curriculum 2013. Then for the as ses sment competence test agreement from 2014 to 2016 implemented by Professional Certification Institute (LSP). The form of Batu city cooperation in SMKN 1 Batu in terms of learning evaluation in 2014, 2015, and 2016 refers to the 2013 curriculum while the form of competency test cooperation from 2014 to 2016 competency test as ses sments conducted by Profes sional Certification Institution (LSP).

The result of cooperation research in the field of competency test is supported by research of Iriani \& Soeharto (2015) with the result of competency test conducted by guidance from DU / DI (100\%) stated strongly agree while with the teacher of counselors in school agree $(75 \%)$. This is supported by the research of Miswardi \& Pardjono (2013) with the result of student learning process in the work place to make the students more experienced with the guidance of the industry involved in guiding the students when the students are in the field by evaluating the learning done by the industry when the students are in field. The result of this research is in line with the research of Widayati \& Isroah (2006) with the result of UKP implementation of approximately $77,143 \%$ is in accordance with the guideline of UKP implementation. The readiness of the school is good enough as evidenced by $100 \%$ graduation rate. However, the quality of graduates should be studied further considering the minimum standard of graduation is a requirement that is pursued by the school. The standard score that students have taken needs to be studied further whether the value indicates the competence of the actual graduate. Certification is still a formality as a consequence of UKP

Cooperation conducted SMKN 2 Malang with PT. Pharos is a collaboration that is done specially for alumni of SMKN 2 Malang especially nursing department and alumni from the health department. $\mathrm{Pt}$ Pharos is one of the largest pharmaceutical companies in Indonesia. PT. Pharos already exist all over Indonesia starting from Jabodetabek, Bandung, Cirebon, Semarang, Yogyakarta, Solo, Surabaya, Malang, Denpasar, Lampung, Palembang, Pekanbaru, Medan, Batam, Makasar, Balikpapan, Samarinda, Banjarmasin. In addition to PT. Pharos SMKN 2 Malang also cooperate with Insan Medika Home Care cooperation done by medika is the opening of a branch of Insan Medika Malang Raya area at SMKN 2 Malang and open recruitment of alumni of a student of SMKN 2 Malang and some health vocational school. Insan Medika is a service provider of home care, companion of sick, and professional elderly nurses, Insan Medika already exist all over Indonesia starting from Jakarta, Bogor, Depok, Tangerang, Bekasi, Bandung, Surabaya, Medan, Makassar, Bali, Lombok, countries like Singapore and Malaysia.

In addition to establishing industrial cooperation with these two industries, SMKN 2 Malang opens online registration for industrial classes in cooperation with the German government, vice principal of SMKN 2 Malang explained the registration of this special line opened after getting permission from the education office of Malang city. The industry class includes two nursing classes and two social nursing classes with a capacity of 32 students per class. In the city of Malang, the SMK appointed by the province to cooperate with Germany is SMKN2 Malang and SMKN 4 Malang from the field of technology.

Vice principal of SMKN 4 Malang explained Cooperation class at SMKN 4 Malang did not open special registration program, but selected students are majoring in Software Engineering (RPL) at class XII with quota 50 students. SMKN 4 Malang trains students who passed the course to be guided during July and June. Cooperation is also done SMKN 4 Malang with PT. Adhinata where the process is done by the tests conducted in class $\mathrm{X}$ that will go up to grade XI in the production department of graphics, in addition to PT. Adhinata SMKN 4 Malang in cooperation with evercross which has been done for one year. The form of cooperation is carried out on every Saturday by bringing in guest teachers from the industry, and for teachers to implement on-the-job training in the industry to improve teachers' ability in learning.

Industrial Classes in SMKN 4 Malang that already have a laboratory is an industry class Multimedia expertise program in collaboration with the evercoss company. In addition to the Multimedia Industry Class, SMKN 4 Malang also opened the industrial class of graphic production in collaboration with the 
company graphics or printing. Schools known as SMK grafika will open an animation industry class. In the industry class, students can get information or updated technology, because the industrial world must follow the development. In addition to involving industry, SMK 4 Malang also took alumni of the learning system. SMKN 4 Malang organizes "Alumni Mengajar" Movement. In that activity, the SMKN 4 Malang will invite alumni to teach and share experiences with the students of SMKN 4 Malang. Many alumni SMKN 4 Malang who occupy the position of manager level in various companies field of graphics.

SMKN 1 Singosari Malang officially began to cooperate with PT. Trakindo Utama since 2004.Trakindo provides teaching and learning facilities ranging from manuals, audiovisual tapes, television sets, videos, to Caterpillar heavy equipment. Trakindo also provides basic mechanic training training to vocational students. The teaching and learning process is complemented by original props, such as tractors, large tools, and Caterpillar machines, and guided by teachers who have received training to produce qualified graduates who are truly ready to enter the workforce.

The effectiveness of cooperation is done in the form of industrial work practices aimed at students can master the competence in accordance with the areas of expertise required DU / DI and get technical experience directly in the production link, DU / DI can empower students to increase the productivity of economic value.

Cooperation model with the industrial world in referral SMK combines theory learning in the classroom and practical learning in the laboratory designed in accordance with the concept of reference SMK in order to produce graduates with quality level ready to enter the work world. Apprenticeship cooperation is conducted as an effort to develop the skills of vocational students in the form of real industrial work that is expected to provide benefits for the industry to utilize as a recruitment program for students who have skills in accordance with their areas of expertise, this is supported by research Indriaturrahmi \& Sudiyatno (2016) students run well because the industry is involved in the final level of student competency test and with industrial prakerin provides training in the form of workshops to improve students' skills competence.

The cooperation pattern of the Training Program is focused on optimizing all existing resources in schools to be used in the training process for the industrial executive officers and also a means to make the partnership with the industry in order to remain sustainable, with the cooperation pattern of this training is expected that the industrial proximity to the school will stay intense, due to mutual bonding and mutual benefit, this is supported by research Inayat, et al. (2013) with the results of training programs conducted through feedback from instructors brought in from industry to help students get better results .

Recruitment activities of direct human resources in schools conducted by the industry with various stages of selection / screening process. The school should prepare the facilities and infrastructure, as one form of service to the business world or industrial world. This activity is carried out by the field of cooperation and service industry, where every there is a demand for human resources both for street vendors and for prospective employees of the company, always support it by sending and accompanying some students / alumni in accordance with the number of human resources demanded. This is supported by the research of Fu'adi, et al (2009) with the achievement of industrial work achievement in class XII students is good with the average 82.8 .

\section{CONCLUSION}

Development of the referral SMK based on the student's quantity road map in Malang raya from 2014 until 2016 can be grouped: 1) the Malang city classified to meet the standards in SMKN 2 Malang with the number of students in 2014 amounted to 2795 students, the year 2015 amounted to 2951 students, the year 2016 amounted to 2955 students. While in SMKN 4 Malang 2014 amounted to 1815 students, 2015 amounted to 1724, and in 2016 amounted to 1873 students. So that the SMK in the Malang city meets the minimum standard of 1000 students; 2) Malang district area there is one of referral vocational that has not fulfilled the criterion. SMKN 1 Singosari 2014 amounted to 1954 students, 2015 amounted to 2039 students, and year 2016 amounted to 2049. While at SMK Muhammadiyah 03 the singosari year 2014 amounted to 783 students, the year 2015 amounted to 712 students, and in 2016 amounted to 748 students so that for the district of Malang one of the referrals SMK not meet the minimum standard number of students for the number of students; and 3) Batu city area in SMKN 1 Batu in 2014 amounted to 914 students, 2015 numbered 991 students, and in 2016 amounted to 996 students. So that the Batu city has not met the criteria of the referral SMK when viewed from the number of students.

Development of the referral SMK based on the industrial cooperation road map in Malang raya from 2014 to 2016 are grouped: 1) Malang City area in SMKN 2 Malang 2014 amounts to 120 industries, 2015 amounts to 135 industries, and in 2016 amounts to 148 industries. While in SMKN 4 Malang 2014 amounted to 180 industries, in 2015 amounted to 200 industries, and in 2016 amounted to 228 industries. So the referral SMK in the Malang city meet the standard of reference SMK with a cooperation of at least 100 industries; 2) the referral SMK in Malang district at SMKN 1 Singosari 2014 amounted to 135 industries, in 2015 amounted to 140 industries, and in 2016 amounted to 177 industries. While SMK Muhammadiyah 3 Singosari 2014 amounted to 105 industries, in 2015 amounted to 120 industries, and in 2016 amounted to 144 industries; 3) Batu city area in SMKN 1 Batu 2014 amounted to 100 industries, 2015 amounted to 105 industries, and in 2016 amounted to 120 industries. Malang Raya for cooperation category meet the criteria for each school from 2014 to 2016 meet the standard in cooperation with 100 industries.

\section{REFERENCES}

[1] Ashriati, N., Alsa, A. and Suprihatin, T, "Hubungan antara dukungan sosial orang tua dengan kepercayaan diri remaja penyandak cacat fisik SLB-D YPAC Semarang”, Jurnal P sikologi Proyeksi, 1(1):47-58, 2006. 
[2] Chryssolouris, G., Mavrikios, D. and Rentzos, L, "The teaching factory: A manufacturing education paradigm", Journal Procedia CIRP, 57 (3): 44-48, 2016.

[3] Fajaryati, N, "Evaluasi Pelaksanaan Teaching Factory SMK di Surakarta.", Jurnal Pendidikan Vokasi, 2(3): 325-337, 2012.

[4] Fu'adi, F., Eko, B., and Murdani., "Hubungan Minat Berwirausaha dengan Prestasi Praktik Kerja Industri Siswa Kelas XII Teknik Otomotif SMK Negeri 1 Adiwerna Kabupaten Tegal tahun Ajaran 2008/2009”, Jurnal PT M, 9(2): 92-98, 2009.

[5] Inayat, I., Amin, R., Inayat, Z., and Salim, S, "Effects of Collaborative Web Based Vocational Education and Training (VET) on Learning Outcomes.”, Journal Computers \& Education, 68(2): 153-166. 2013.

[6] Indriaturrahmi., and Sudiyatno, "Peran Dunia Usaha dan Dunia Industri dalam Penyelenggaraan SMK berbasis Kearifan Lokal di Kota Mataram", Jurnal Pendidikan Vokasi, 6(2): 162-172, 2016.

[7] Iriani, S., and Soeharto, "Evaluasi Pelaksanaan Praktik Kerja Industri Siswa Kompetensi Keahlian Jasa Boga SMKN 3 Purworejo”, Jurnal Pendidikan Teknologi dan Kejuruan, 22(2): 274-290, 2015.

[8] Iskandar, N., Setiawan, A., and Sumardi, K, “ Identifikasi faktor-faktor yang mempengaruhi siswa SMK memilih program keahlian Teknik mesin", Journal of Mechanical Engineering Education, 3(2): 90-97, 2016.

[9] Ixtiarto, S., and Sutrisno, "Kemitraan sekolah menengah kejuruan dengan dunia usaha dan dunia industry", Jurnal Pendidikan ilmu social, 26(1). ISSN: 1412-3835, 2016.

[10] Jatmoko, D, "Relevansi Kurikulum SMK Kompetensi keahlian Teknik Kendaraan Ringan Terhadap Kebutuhan Dunia Industri di Kabupaten Sleman”, Jurnal Pendidikan Vokasi, 3(1): 1-13, 2013.

[11] Kurniasari and Isnani, "Analisis Pelaksanaan Kerjasama SMK dengan Dunia Usaha", Jurnal Pendidikan Bisnis dan Manajemen. 1 (2): 1-70, 2015.
[12] Marini, K., and Hamidah, S, "Pengaruh Self-Efficacy, Lingkungan Keluarga, dan Lingkungan Sekolah Terhadap Minat Berwirausaha Siswa SMK Jasa Boga”, Jurnal Pendidikan Vokasi, 4(2): 195-207, 2014.

[13[ Miswardi, Y., and Pardjono, "Proses dan Hasil Belajar pada Prakerin Bidang Keahlian Kendaraan Ringan: Studi Kasus pada Industri Pasangan SMKN 3 Yogyakarta", Jurnal Pendidikan Vokasi, 3(1): 268281., 2013.

[14] Mukhadis, A, “Metodologi Penelitian Kuantitatif”, Malang: Aditya Media Publishing, 2016.

[15] Munadi, S, "Faktor-faktor yang mempengaruhi minat siswa SMP masuk SMK di kota Pontianak", Jurnal pendidikan vokasi, 4(3): 1-8, 2014.

[16] Nurmala, S, "Faktor-faktor yang mempengaruhi minat siswa untuk melanjutkan ke sekolah menengah kejuruan", Jurnal kependidikan, 42(2):162-172, 2012.

[17] Retnawati, H., Hadi, S., and Nugraha, C, "Implemetasi Pemanfaatan Soft ware Penulisan laporan Hasil belajar Siswa SMK pada Pelaksanaan Kurikulum 2013”, Jurnal Pendidikan Vokasi, 7(1): 30-42, 2016.

[18] Rochmadi, S, “ Model Pembelajaran Teknik Survei dan Pemetaan SMK Melalui Kemitraan Dengan Dunia Kerja”, 2014.

[19] Wibowo, N, "Upaya memperkecil kesenjangan kompetensi lulusan sekolah menengah kejuruan dengan tuntutan dunia industri", Jurnal pendidikan teknologi dan kejuruan, 23(1): 256-262, 2016.

[20] Widayati, A., and Isroah, "Evaluasi Pelaksanaan Uji Kompetensi Produktif SMK Program Keahlian Akuntasi”, Jurnal Pendidikan Akuntasi Indonesia, 5(1): 85-97, 2006.

[21] Windarto, R, "Minat Siswa SMP Negeri Melanjutkan ke SMK ditinjau dari Sosial Ekonomi Keluarga di Kabupaten Bantul", Jurnal Pendidikan Vokasi, 3(1): 103-116, 2013. 